\title{
HUBUNGAN ANTARA GOOD CORPORATE GOVERNANCE DAN STRUKTUR KEPEMILIKAN DENGAN KINERJA KEUANGAN
}

\author{
Anik Malikah \\ Fakultas Ekonomi Universitas Islam Malang (UNISMA) \\ J1. MT. Haryono No.193 Malang
}

\begin{abstract}
Agency Theory say if principal and agent (manager) have different of interest, will make agency conflict Separate of function about owner (shareholder) with manager will make negative effect like management freedom to maximize profit for themselves. This condition will happened caused asymmetry information among management and the other party that have no access information about firm. So there were not enough to oversee behavior of management.

This Study intend to know the correlation Good Corporate Governance and ownership structure with company performance. Good corporate governance and ownership structure as independent variable and company performance as dependent variable. We use two pillar of Good Corporate Governance. There are transparency and accountability. Transparency is peroxide by disclosure of financial statement and accountabilities peroxide by accruals. Company performance is peroxide by Tobin's $Q$.

The population are company that list in LQ 45 during 2 semester. The result of this study is: (1) there is no correlation about ownership structure with company performance. (2) There are no correlation about accountability with company performance, (3) there are significant correlation about transparency with company performance.
\end{abstract}

Key words: good corporate governance, ownership structure, financial performance

Sejak krisis keuangan melanda Asia pertengahan tahun 1997, Indonesia merupakan negara yang mengalami krisis paling parah dan paling lama dalam proses pemulihannya. Kurs rupiah terhadap dollar jatuh sampai mencapai Rp.16,000, pertumbuhan ekonomi negatif di tahun 1998, kredit macet menggunung mencapai $70 \%$ kredit sektor perbankan dalam negeri, suku bunga simpanan melonjak sampai ke angka 65\% pertahun, sektor riil berhenti beroperasi dan pengangguran terbuka melonjak drastis (Mories: 2002)

Sudah tiga Presiden memimpin Indonesia selama masa krisis namun krisis di Indonesia masih belum memperlihatkan tanda-tanda akan berakhir. Indikator-indikator makro ekonomi menunjukkan bahwa tingkat perekonomian 
kita masih di bawah dari sebelum terjadinya krisis, kurs rupiah yang masih tinggi, pengangguran yang semakin meningkat, kinerja ekspor yang belum membaik dan investasi asing belum banyak mau masuk.

Good Corporate Governance merupakan standar manajemen mutu sebuah korporat (perusahaan)/ pemerintahan/ semua aktor pembuat kebijakan publik dalam proses penyelenggaraan manajerial dan pengambilan keputusan/ kebijakan strategis secara proporsional dan orientasi positif. Dalam definisi lainnya good corporate governance merupakan prinsip pengelolaan perusahaan yang bertujuan mendorong kinerja perusahaan serta memberikan nilai ekonomis bagi pemegang saham. Dalam kata lain prinsip good corporate governance mengandung arti bahwa pengelolaan perusahaan harus diikuti dengan pengawasan yang efektif terhadap manajemen, sehingga tindakan manajemen yang dapat merugikan dan menyebabkan pailit dapat dicegah.

Monk dan Mino (Media Akuntansi: 2000), menyatakan bahwa dalam konsep good corporate governance terhadap prinsip-prinsip dasar yang meliputi transparansi, integritas, akuntabilitas, keadilan dan responsibilitas. Berbagai prinsip ini mengharuskan perusahaan untuk memberikan laporan bukan saja kepada pemegang saham, calon investor, kreditur atau pemegang saham saja tetapijuga pada stakeholder lainnya.

Laporan ini berfungsi sebagai media pertanggungjawaban perusahaan kepada semua pihak yang berkepentingan dengan perusahaan. Laporan yang diberikan perusahaan menunjukkan tingkat kinerja yang dicapai oleh perusahaan dalam pengelolaan sumber daya yang dimiliki untuk memberi nilai tambah kepada stakeholders. Laporan pertanggungjawaban perusahaan ini secara umum disajikan dalam bentuk laporan keuangan yang diterbitkan setiap setahun sekali.

Permasalahan yang timbul dalam good corporate governance merupakan akibat adanya masalah keagenan yang muncul dalam satu organisasi. Berkaitan dengan struktur kepemilikan, terjadi ketidakselarasan kepentingan antara dua kelompok pemilik perusahaan, yaitu controlling dan minority shareholders. Seringkali controlling shareholders mengendalikan keputusan manajemen yang merugikan minority shareholders. Selain itu struktur kepemilikan yang menyebar (manager-controlled) juga memberikan kontribusi lebih terhadap terjadinya 
masalah keagenan daripada struktur kepemilikan yang terkonsentrasi (ownercontrolled). Namun demikian Husnan (2000), menyatakan secara empiris ditemukan bukti bahwa perusahaan yang kepemilikannya lebih menyebar memberikan imbalan yang lebih besar kepada manajemen dibandingkan dengan perusahaan yang kepemilikannya lebih terkonsentrasi.

Laporan keuangan merupakan jembatan antara pihak internal yaitu manajemen dengan pihak eksternal seperti kreditor, investor dan pemerintah. Namun pada praktiknya yang menjadi fokus perhatian pihak-pihak eksternal hanya pada laba (earnings) yang terdapat pada laporan laba/rugi. Hubungan keagenan yang terjadi antara manajemen (agen) dan pemilik (principle) membebankan tanggung jawab stewardships untuk melaporkan kinerja perusahaan dalam bentuk laporan keuangan. Dalam kondisi demikian manajer mempunyai dorongan untuk melakukan manipulasi laba/manajemen laba (earnings management) melalui pemilihan kebijakan akuntansi dari standar akuntansi yang ada untuk memaksimalkan kesejahteraan perusahaan dan atau manajer itu sendiri. Secara lebih khusus, kebijakan accrual (discretionary accrual) digunakan sebagai ukuran rekayasa kebijakan akrual yang mengarahkan suatu kepentingan tertentu pihak manajemen perusahaan publik.

Kinerja perusahaan dipengaruhi oleh beberapa faktor, antara lain terkonsentrasi atau tidak terkonsentrasinya kepemilikan, manipulasi laba, serta pengungkapan laporan keuangan. Kepemilikan yang banyak terkonsentrasi oleh institusi akan memudahkan pengendalian sehingga akan meningkatkan kinerja perusahaan. Disclosure sebagai salah satu aspek good corporate governance diharapkan dapat menjadi dasar untuk melihat baik tidaknya kinerja perusahaan. Hal ini kontradiktif dengan perilaku oportinis manajemen yang memainkan accruals untuk memanipulasi laba.

Berdasarkan latar belakang yang diuraikan di atas, penelitian ini merupakan replikasi dari penelitian Nurhayani (2004). Penelitian ini menggunakan ukuran integritas laporan keuangan yang disajikan oleh akuntan publik yang independen, sebagai media pertanggungjawaban perusahaan kepada semua pihak yang berkepentingan (stakeholders) dengan perusahaan yang dapat mencerminkan pengungkapan atas informasi perusahaan yang kredibel dimata publik. Di samping pentingnya implementasi mekanisme good corporate 
governance merupakan faktor lain yang diduga mempengaruhi tinggi rendahnya integritas laporan keuangan perusahaan publik, yang diukur dengan discretionary accrual sebagai proksi manajemen laba (earnings management).

Blair (1995) Corporate governance adalah keseluruhan aset aransemen legal kebudayaan, dan institusional yang menentukan apa yang dapat dilakukan oleh perusahaan publik, siapa yang mengendalikan, bagaimana pengendalian dilakukan, dan bagaimana resiko dan return dari aktivitas-aktivitas yang dilakukan oleh perusahaan tersebut dialokasikan.

Strukur kepemilikan dan kontrol telah menjadi inti teori modern perusahaan yang menjadi perdebatan ilmiah sejak presentasi Berle dan Means (1932) dan pembahasan lebih formal oleh Jensen dan Meckling (1976) yang terkenal dengan The Modern Corporation and Private Property. Intinya adalah masalah keagenan karena konflik kepentingan antara para manajer dan para pemegang saham. Suatu pendapat bahwa para manajer mengabaikan kepentingan para pemegang saham berasal dari fakta bahwa pemegang saham perusahaan-perusahaan besar adalah tersebar luas dan berada jauh dari perusahaannya. Dalam bentuk modern suatu perusahaan yang dengan kepemilikan yang tersebar luas, resolusi konflik kepentingan antara residual claimant dan para manajer menjadi isu sentral dan menentukan struktur kepemilikan suatu perusahaan.

Struktur kepemilikan yang lebih terkonsentrasi akan meminimalkan problem keagenan karena jalinan yang lebih kuat antara kepentingan para pemegang saham dan para manajer. Pada tipe perusahaan semacam ini, ada dua kelompok pemegang saham, yaitu: 1 . Kelompok pemegang saham pengendali. 2. Kelompok pemegang saham minoritas.

Di Indonesia, pemegang saham pengendali berfungsi sebagai pemilik, dimana kepentingan mengendalikan perusahaan lebih dominan, sedangkan pemegang saham minoritas berfungsi sebagai investor yang lebih mengharapkan capital gains. Karakteristik kelompok ini banyak ditemui pada perusahaanperusahaan yang terdaftar pada bursa di Indonesia (konglomerat) dan di Korea (chaebol) (Piteris, 2002) dalam Umar (2003). Penelitian La Porta et al., 2000; (Facio dan Lang, 2002) dalam Umar (2003) menemukan bahwa problem keagenan relevan bukanlah problem antara para pemegang saham pengendali dan para 
pemegang saham minoritas. Masalah utamanya justru menjadi kontrol pengkhianatan pemegang saham pengendali terhadap pemegang saham minoritas.

Kinerja keuangan menurut Warsono (2003) adalah "suatu gambaran penelitian terhadap kinerja keuangan perusahaan dengan menggunakan input laporan keuangan". Metode analisis laporan keuangan yang dapat digunakan saat ini adalah analisis rasio keuangan. Dalam metode analisis laporan keuangan ini, suatu perusahaan dapat memilih salah satu atau beberapa analisis yang sesuai dengan kondisi perusahaannya. Hal ini disebabkan karena tidak semua analisis laporan keuangan dapat diterapkan pada semua perusahaan, karena masing-masing metode analisis mensyaratkan kondisi tertentu.

Pengungkapan dalam laporan keuangan sangat dipengaruhi oleh perkembangan pasar modal. Tujuan laporan keuangan adalah memberikan informasi bagi para pemakai laporan keuangan untuk pengambilan keputusan ekonomisnya. Semakin banyak perusahaan yang Go Publik semakin banyak pula pihak yang memerlukan informasi tersebut yang artinya bahwa pihak-pihak yang memerlukan informasi tersebut makin memperlihatkan kualitas-kualitas dari pelaporan keuangan dari perusahaan yang telah menawarkan efeknya melalui pasar modal para pemegang saham berkepentingan terhadap laporan keuangan dalam hubungannya dengan masalah-masalah penggajian, kompensasi bagi manajer, dan persetujuan atas perubahan kebijakan perusahaan yang mendasar. Para pemegang saham umumnya sangat memerlukan pada saat diadakannya RUPS (Rapat Umum Pemegang Saham). Bagi para investor erat kaitannya dengan keputusan bay-sel-hold suatu efek. Sedangkan bagi para kreditor lebih banyak berkaitan dengan masalah pemberian kredit bagi perusahaan. Selain dari pihak-pihak tersebut, pemerintah juga berkepentingan terhadap kewajiban perpajakan ataupun kewajiban lainnya yang dipersyaratkan oleh pemerintah kepada perusahaan yang bersangkutan. Pada umumnya diasumsikan informasi yang berguna bagi investor dan kreditor juga berguna bagi pihak lainnya (Hendriksen, 1994)

Pengungkapan (disclosure) merupakan suatu istilah yang relatif, akan tetapi merupakan tujuan apa informasi keuangan itu disajikan. Sesuai dengan postulat-postulat dasar akuntansi, data keuangan yang paling relevan harus 
diikhtisarkan dalam bentuk laporan yang formal dan selanjutnya dalam catatan kaki, skedul pelengkap, dan ikhtisar pelengkap. Informasi deskriptif hanya perlu terlihat dalam batang tubuh laporan dalam bentuk yang ringkas uraian yang lebih terinci harus tampak dalam catatan kaki atau tempat lain dalam laporan keuangan (Hendriksen, 1994: 221)

\section{METODE}

Jenis penelitian yang digunakan dalam penelitian ini merupakan studi kasus dengan kerangka konseptual sebagai berikut:

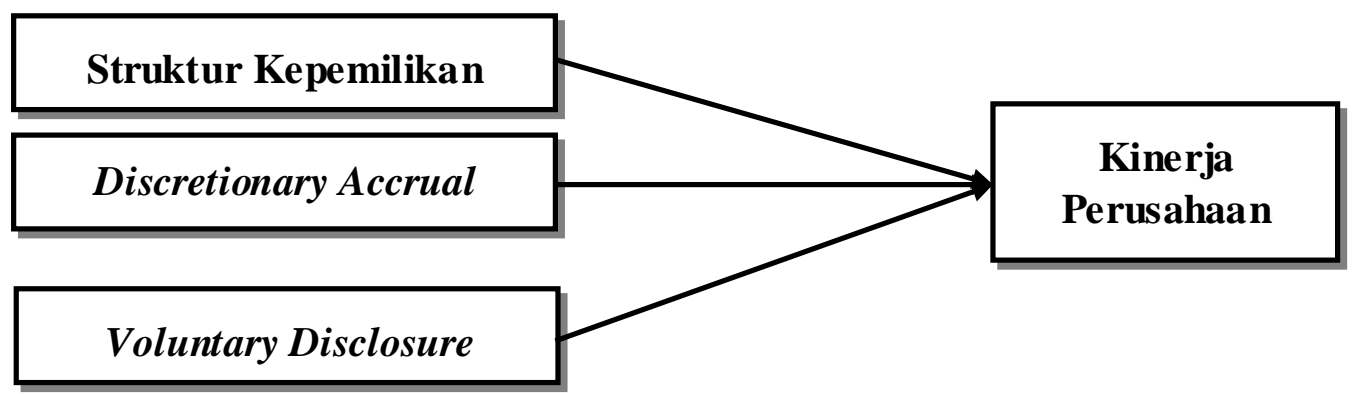

Penelitian ini menggunakan data kuantitatif pada perusahaan yang listing di bursa efek Jakarta yaitu sebanyak 296 perusahaan yang terdaftar dari tahun 2005-2008, dan yang memenuhi kriteria sebagai sampel sebanyak 18 perusahaan. Teknik pengumpulan data dalam penelitian ini adalah teknik dokumentasi yaitu pengumpulan data yang diperoleh dengan cara melihat, mencatat, menganalisis dan mengevaluasi data sekunder yang diperoleh dari perusahaan yang listing di bursa efek Jakarta.

Dalam penelitian ini, digunakan variable terikat (dependent variable) yaitu kinerja perusahaan, sedangkan variable bebas (independent variable) yaitu variabel struktur kepemilikan, variabel discretionary accroals, variabel voluntary disclosure.

\section{Definisi operasional}

1. Struktur kepemilikan merupakan suatu alat untuk mengurangi konflik kepentingan diantara para pemegang klaim (claimholders) utama yang ada dalam perusahaan (Jensen dan Meckling, 1976). Proporsi kepemilikan diwakili oleh variabel dummy, 1 untuk kepemilikan terkonsentrasi (mayoritas) dan 0 untuk kepemilikan menyebar. Kepemilikan terkonsentrasi adalah ada institusi atau pemerintah yang memiliki prosentase yang tinggi 
sedangkan kepemilikan menyebar adalah saham-saham dimiliki secara merata oleh pemegang saham.

2. Discretionary accruals sebagai proksi manipulasi yang dilakukan manajemen. Discretionary accruals merupakan selisih total accruals dan non discretionary accruals. Sedangkan total accruals merupakan selisih antara net income dan cash flow from operations. Total accruals dipecah menjadi komponen discretionary accruals dan non discretionary accruals dengan menggunakan Modified Jones Model (Dechow at al, 1995). AC = net income - cashflow from operations

Current accruals (CA) didefinisikan sebagai perubahan dalam non cash current assets dikurangi perubahan dalam operating current liabilities. Dirumuskan sebagai berikut: $\mathrm{CA}=\Delta$ (current assets - cash $)-\Delta$ (current liabilities - current maturity of long ternm debt)

Non Discretionary Accruals (NDA) merupakan accruals yang diekspektasi dengan merupakan Modified Jones Model. Expected Current Accruals sebuah perusahaan di tahun tertentu diestimasi menggunakan cross sectional Ordinary Least Square (OLS) Regression terhadap current accruals dan perubahan penjualan.

$$
\frac{\mathrm{CA}_{\mathrm{i}, \mathrm{t}}}{\mathrm{TA}_{\mathrm{i}, \mathrm{t}-1}}=\mathrm{a}_{1}\left(\frac{1}{\mathrm{TA}_{\mathrm{i}, \mathrm{t}-1}}\right)+\mathrm{a}_{2}\left(\frac{\Delta \text { Sales }_{\mathrm{i}, \mathrm{t}}}{\mathrm{TA}_{\mathrm{i}, \mathrm{t}-1}}\right)
$$

Non discretionary accruals (NDA) dihitung sebagai berikut:

$$
N D A i, \mathrm{t}=\mathrm{a}_{1}\left(\frac{1}{\mathrm{TA}_{\mathrm{i}, \mathrm{t}-1}}\right)+\mathrm{a}_{2}\left(\frac{\Delta \text { Sales }_{\mathrm{i}, \mathrm{t}}-\Delta \mathrm{TR}_{\mathrm{i}, \mathrm{t}}}{\mathrm{TA}_{\mathrm{i}, \mathrm{t}-1}}\right)
$$

Dimana:

$\mathrm{a}_{1} \quad=$ Estimated intercept untuk perusahaan $i$ pada tahun $t$

$\mathrm{a}_{2} \quad=$ Koefisien kemiringan (slope) untuk perusahaan i pada tahun $\mathrm{t}$

$\mathrm{TA}_{\mathrm{i}, \mathrm{t}-\mathrm{1}} \quad=$ Total assets pada periode $\mathrm{t}-1$

$\Delta$ Sales $\quad=$ Perubahan penjualan

$\Delta \mathrm{TR} \quad=$ Perubahan dalam piutang dagang

Discretionary current accruals (DCA) untuk sebuah perusahaan pada tahun tertentu dihitung sebagai berikut:

$$
D C A_{i, t}=\frac{C A_{i, t}}{T A_{i, t-1}}-\mathrm{NDCA}_{\mathrm{i}, \mathrm{t}}
$$

Untuk menghitung discretionary dan non discretionary longterm accruals (DLTA dan NDLTA), harus menghitung discretionary dan non discretionary total 
accruals (DTA dan NDTA). Discretionary total accruals (NDTA) sebuah perusahaan di tahun tertentu dihitung meregresi total accruals (AC) sebagai dependent variable dan gross property, plant and equipment (PPE) sebagai additional explanatory variable.

$$
\frac{\mathrm{AC}_{\mathrm{i}, \mathrm{t}}}{T A_{i, t-1}}=\hat{b}_{o}\left(\frac{1}{T A_{i, t-1}}\right)+\hat{b}_{1}\left(\frac{\Delta \text { Sales }_{i, t}-\Delta T K_{i, t}}{T A_{i, t-1}}\right)+\hat{b}_{2}\left[\frac{P P E_{i, t}}{T A_{i, t-1}}\right]
$$

Non discretionary total accruals (NDTA) dihitung sebagai berikut:

$$
\mathrm{NDTA}_{i, t}=\hat{b}_{o}\left(\frac{1}{T A_{i, t-1}}\right)+\hat{b}_{1}\left(\frac{\Delta \text { Sales }_{i, t}-\Delta T R_{i, t}}{T A_{i, t-1}}\right)+\hat{b}_{2}\left[\frac{P P E_{i, t}}{T A_{i, t-1}}\right]
$$

Dimana:

bo $\quad=$ Estimated intercept untuk perusahaan $i$ pada tahun $\mathrm{t}$

$\mathrm{b} 1, \mathrm{~b} 2=$ Koefisien kemiringan (slope) untuk perusahaan i pada

PPE $\quad$ = $\quad$ Gross property, plant and equipment

$T A_{i, t-1} \quad=$ Total assets pada periode $\mathrm{t}-1$

$\Delta$ Sales $\quad=$ Perubahan penjualan

$\Delta T R=$ Perubahan dalam piutang dagang

3. Disclosure diukur dengan index yang dipakai oleh Cooke (1992) dan Wallace (1987) dengan rumus indeks $=\mathrm{n} / \mathrm{k}, \mathrm{n}$ menunjukkan jumlah item yang mungkin dipenuhi.

4. Kinerja perusahaan merupakan suatu penilaian perusahaan terhadap posisi keuangan dan mengelola sumber daya yang ada dimana informasi sumber daya, struktur keuangan, likuiditas, solvabilitas, profitabilitas, aktivitas dan kemampuan beradaptasi terhadap perubahan lingkungan diperlukan untuk memprediksikan kemampuan perusahaan dalam memenuhi komitmen keuangannya sehingga dari prediksi tersebut dapat diketahui, kemampuan kinerja keuangan apakah baik atau tidak

Kinerja perusahaan diukur dengan rumus Q-tobin

$\mathrm{Q}-\mathrm{TOBIN}=\frac{\text { nilai pasar equitas }+ \text { nilai buku utang }}{\text { nilai buku totalaktiva }}$ (Hastuti, 2005:242)

\section{HASIL DAN PEMBAHASAN}

Hasil 
Dalam penelitian ini analisis yang digunakan adalah analisis kuantitatif yaitu data yang berupa angka-angka yang dikumpulkan berdasrkan kinerja keuangan pada perusahaan yang listing di bursa efek jakarta. Untuk dianalisis kemudian diambil suatu kesimpulan. Untuk mengetahui faktor penentu kinerja keuangan pada perusahaan yang listing di Bursa Efek Indonesia. Maka peneliti menggunakan beberapa variabel diantaranya yaitu struktur kepemilikan, discretionary acctual dan voluntary disclosure.

\section{Uji normalitas}

Tujuan dari uji asumsi normalitas adalah untuk mengetahui apakah dari validitas dan reliabilitas mempunyai distribusi normal atau tidak. Model normalitas yang baik adalah berdistribusi normal atau mendekati normal. Menurut H.W Lilliefors memperkenalkan sejenis uji Kolmogorof Smirnov untuk menguji kenormalan data tanpa perlu menetapkan nilai rata-rata dalam ragam distribusi normal. Adapun pedoman dalam pengambilan keputusan bahwa suatu data dapat dikatakan normal apabila nilai signifikansi pada kolom uji Kolmogorov Smirnov lebih dari 0,05

Tabel 1

Uji Normalitas

\begin{tabular}{|l|c|c|c|c|}
\hline \multicolumn{1}{|c|}{ Variabel } & $\begin{array}{c}\text { Kolmogorof } \\
\text { Smirnof Z }\end{array}$ & $\begin{array}{c}\text { Asymp } \\
\text { Sig }\end{array}$ & $\begin{array}{c}\text { Nilai } \\
\text { Kritis }\end{array}$ & Keterangan \\
\hline Kinerja Perusahaan & 1.051 & 0.220 & $>0,05$ & Berdistribusi Normal \\
\hline $\begin{array}{l}\text { Struktur } \\
\text { Kepemilikan }\end{array}$ & 1.125 & 0.183 & $>0,05$ & Berdistribusi Normal \\
\hline $\begin{array}{l}\text { Discretionary Current } \\
\text { Accrual (DCA) }\end{array}$ & 0.965 & 0.309 & $>0,05$ & Berdistribusi Normal \\
\hline DiscVoluntarylosure & 1.158 & 0.137 & $>0,05$ & Berdistribusi Normal \\
\hline
\end{tabular}

Dari uraian di atas dapat diketahui bahwa seluruh variabel, dalam penelitian ini memiliki asymp sig $>0,05$. Sehingga dapat disimpulkan bahwa semua variabel memiliki data yang berdistribusi normal.

\section{Uji Asumsi Klasik}

1. Uji Autokorelasi

Pengujian autokorelasi dilakukan dengan menggunakan durbin watson $\mathrm{t}$ test dengan hasil pada tabel berikut: 
Tabel 2

Uji Autokorelasi

\begin{tabular}{|c|c|c|c|c|c|}
\hline Model & $\begin{array}{c}\text { DW } \\
\text { statistik }\end{array}$ & $\mathrm{dL}$ & $\mathrm{dU}$ & $\begin{array}{c}\text { Range } \\
\text { Du<DW }<4-\mathrm{dU}\end{array}$ & Ket: bebas \\
\hline $\begin{array}{c}\text { Tanpa } \\
\text { interaksi }\end{array}$ & 1,949 & 1,583 & 1,801 & $1,801<1,949<2.199$ & Autokorelasi \\
\hline
\end{tabular}

Sumber: Data diolah

Tabel 2, menunjukkan baha DW statistik terletak dalam range $\mathrm{Du}<\mathrm{DW}<4-\mathrm{dU}$, hal ini berarti bahwa masing-masing model bebas masalah autokorelasi

2. Uji Heterokedastisitas

Pengujian heterokedastisitas dilakukan menggunakan metode GletserTest. Prosedur ini dilakukan dengan terlebih dahulu mencari nilai residual kemudian dilakukan regresi nilai residual tersebut sebagai variabel dependent terhadap variabel bebas.

Adapun hasil dari uji heterokedastisitas ini adalah sebagaimana terlihat pada tabel berikut ini:

Tabel 3.

\section{Gletser-test}

Coefficients $^{a}$

\begin{tabular}{|c|c|c|c|c|c|c|c|c|}
\hline \multirow[b]{2}{*}{ Mod } & & \multicolumn{2}{|c|}{$\begin{array}{l}\text { Unstandardized } \\
\text { Coefficients }\end{array}$} & \multirow{2}{*}{$\begin{array}{c}\begin{array}{c}\text { Standardized } \\
\text { Coefficients }\end{array} \\
\text { Beta }\end{array}$} & \multirow[b]{2}{*}{$t$} & \multirow[b]{2}{*}{ Sig. } & \multicolumn{2}{|c|}{ Collinearity Statistics } \\
\hline & & B & Std. Error & & & & Tolerance & VIF \\
\hline \multirow[t]{4}{*}{1} & (Constant) & -1.628 & .821 & & -1.982 & .052 & & \\
\hline & Mlik & .191 & .188 & .122 & 1.015 & .314 & .871 & 1.149 \\
\hline & DCA & .153 & .058 & .298 & 2.648 & .010 & .995 & 1.005 \\
\hline & Disclosure & .635 & .529 & .145 & 1.199 & .235 & .867 & 1.153 \\
\hline
\end{tabular}

a. Dependent Variable: Kinerja Perusahaan

Pada tabel 3 menunjukkan bahwa seluruh variabel bebas yang terdiri dari Struktur Kepemilikan, Discretionary Current Accrual (DCA) dan Voluntary Disclosure memiliki $\mathrm{t}$ hitung dengan tingkat signifikansi masing-masing berada diatas 0,05. Hal ini menunjukkan bahwa variabel bebas tidak berpengaruh signifikan terhadap absolut residual, yang berarti pula model memenuhi asumsi heteroskedastisitas.

3. Uji Multikolinearitas

Hasil uji multikolinearitas dapat dilihat pada tabel berikut ini: 
Tabel 4

Uji multikolinieritas

\begin{tabular}{|l|c|c|c|}
\hline \multicolumn{1}{|c|}{ Variabel } & Tolerance & VIF & Keterangan \\
\hline Struktur Kepemilikan & 0.871 & 1.149 & Bebas Mutikolinieritas \\
\hline $\begin{array}{l}\text { Discretionary Current } \\
\text { Accrual (DCA) }\end{array}$ & 0.995 & 1.005 & Bebas Mutikolinieritas \\
\hline Disclosure & 0.867 & 1.153 & Bebas Mutikolinieritas \\
\hline
\end{tabular}

Berdasarkan tabel 4, variabel Struktur Kepemilikan memiliki VIF sebesar 1.149, variabel Discretionary Current Accrual (DCA) memiliki VIF sebesar 1.005, dan variabel Disclosure memiliki VIF sebesar 1.153. Mengingat seluruh variabel bebas memiliki VIF $<10$, maka dapat dikatakan bahwa seluruh variabel memenuhi asumsi multikolinearitas.

\section{Pembahasan}

Berdasarkan hasil regresi linier berganda sebagaimana pada tabel berikut

Tabel 5

Hasil Analisis Regresi Berganda

\begin{tabular}{|c|c|c|c|c|c|}
\hline No & & Variabel & $\mathbf{b}$ & t-stat & Sig \\
\hline 1 & Stru & r Kepemilikan & 0.191 & 1.015 & 0.314 \\
\hline 2 & Disc & onary Current Accrual (DCA) & 0.153 & 2.648 & 0.010 \\
\hline 3 & $\overline{\text { Disc }}$ & & 0.635 & 1.199 & 0.235 \\
\hline \multirow{3}{*}{\multicolumn{2}{|c|}{$\begin{array}{l}\text { Constanta } \\
R\end{array}$}} & $=-1.628$ & F uji & \multicolumn{2}{|c|}{$=3.769$} \\
\hline & & $=0.378$ & Sig & \multirow{2}{*}{\multicolumn{2}{|c|}{$=0.015$}} \\
\hline & & $R$ Square & & & \\
\hline
\end{tabular}

Sumber: data diolah, 2008

Berdasarkan hasil analisis didapatkan $\mathrm{R}$ square sebesar 0,143. Hal ini berarti bahwa sebesar $14.3 \%$ perubahan Kinerja Perusahaan (Qtobin) dipengaruhi oleh Struktur Kepemilikan, Discretionary Current Accrual (DCA) dan Disclosure. Sedang sisanya sebesar $85.7 \%$ dipengaruhi oleh faktor lain yang tidak dimasukkan dalam model.

Berdasarkan hasil analisis F uji sebesar 3.769 dengan tingkat signifikansi sebesar 0.015. Oleh karena tingkat signifikansi F pada model ini < 0,05, maka hal ini berarti bahwa secara serentak Struktur Kepemilikan, Discretionary Current Accrual (DCA) dan Disclosure berpengaruh signifikan terhadap Kinerja Perusahaan (Qtobin).

Hasil pengujian Uji $t$ dapat dilihat pada tabel sebagai berikut: 
Tabel 6

Hasil Uji $t$

\begin{tabular}{|c|l|c|r|}
\hline No & \multicolumn{1}{|c|}{ Variabel } & t-stat & \multicolumn{1}{c|}{ Sig } \\
\hline 1 & Struktur Kepemilikan & 1.015 & 0.314 \\
\hline 2 & Discretionary Current Accrual (DCA) & 2.648 & 0.010 \\
\hline 3 & Disclosure & 1.199 & 0.235 \\
\hline
\end{tabular}

Sumber: data diolah, 2008

a. Variabel Struktur Kepemilikan memiliki t uji sebesar 1.015 dengan tingkat signifikansi sebesar 0.314. Oleh karena tingkat signifikansi $>0,05$, maka $\mathrm{H}_{1}$ ditolak. Atau dengan kata lain secara parsial variabel Struktur Kepemilikan tidak berpengaruh terhadap Kinerja Perusahaan (Qtobin). Bila dilihat dari koefisien regesinya yang bernilai positif, hal ini berarti bahwa semakin tinggi tingkat Struktur Kepemilikan maka kinerja perusahaan akan semakin tinggi pula. Hasil penelitian ini konsisten dengan Hastuti (2005) yang menemukan bahwa Struktur Kepemilikan tidak berpengaruh terhadap Kinerja Perusahaan (Qtobin).

b. Variabel Discretionary Current Accrual (DCA) memiliki t uji sebesar 2.648 dengan tingkat signifikansi sebesar 0.010. Oleh karena tingkat signifikansi < 0,05, maka $\mathrm{H}_{2}$ diterima. Dengan kata lain secara parsial variabel Discretionary Current Accrual (DCA) berpengaruh signifikan terhadap Kinerja Perusahaan (Qtobin). Bila dilihat dari koefisien regresi yang bernilai positif, hal ini menunjukkan bahwa Discretionary Current Accrual (DCA) berpengaruh positif signifikan terhadap Kinerja Perusahaan (Qtobin). Hasil penelitian ini konsisten dengan hasil penelitian Hastuti (2005) yang menemukan bahwa Discretionary Current Accrual (DCA) berpengaruh positif signifikan terhadap Kinerja Perusahaan (Qtobin).

c. Variabel Disclosure memiliki t uji sebesar 1.199 dengan tingkat signifikansi sebesar 0.235. Oleh karena tingkat signifikansi $>0,05$, maka $\mathrm{H}_{3}$ ditolak. Atau dengan kata lain variabel Disclosure tidak berpengaruh terhadap Kinerja Perusahaan (Qtobin). Bila dilihat dari hasil koefisien regresinya yang bernilai positif, hal ini mengisyaratkan bahwa semakin banyak perusahaan melakukan pengungkapan maka akan semakin meningkatkan kinerja perusahaan (Qtobin). Hasil ini konsisten dengan hasil penelitian Hastuti 
(2005) yang menemukan bahwa Disclosure tidak berpengaruh terhadap Kinerja Perusahaan (Qtobin).

\section{KESIMPULAN DAN SARAN}

\section{Kesimpulan}

Berdasarkan hasil analisis dan pembahasan maka dapat diraih kesimpulan sebagai berikut:

1. Secara parsial variabel Struktur Kepemilikan tidak berpengaruh terhadap Kinerja Perusahaan (Qtobin). Bila dilihat dari koefisien regesinya yang bernilai positif, hal ini berarti bahwa semakin tinggi tingkat Struktur Kepemilikan maka kinerja perusahaan akan semakin tinggi pula.

2. Secara parsial variabel Discretionary Current Accrual (DCA) berpengaruh signifikan terhadap Kinerja Perusahaan (Qtobin). Bila dilihat dari koefisien regresi yang bernilai positif, hal ini menunjukkan bahwa Discretionary Current Accrual (DCA) berpengaruh positif signifikan terhadap Kinerja Perusahaan (Qtobin).

3. Secara parsial variabel Disclosure tidak berpengaruh terhadap Kinerja Perusahaan (Qtobin). Bila dilihat dari hasil koefisien regresinya yang bernilai positif, hal ini mengisyaratkan bahwa semakin banyak perusahaan melakukan pengungkapan maka akan semakin meningkatkan kinerja perusahaan (Qtobin).

\section{Saran}

1. Sebaiknya perusahaan mengupayakan untuk memenuhi standar minimal disclosure yang harus dipenuhi karena disclosure memang efektif digunakan sebagai alat monitoring untuk meningkatkan kinerja perusahaan.

2. Hendaknya penelitian yang akan datang dapat meningkatkan cara mendeteksi tindakan earning management dengan model yang telah teruji power of test-nya. Selain itu penelitian yang akan datang juga dapat mengamati earnings management dengan periode waktu, jumlah sampel maupun event yang berbeda. 
3. Perlu mekanisme pengendalian intern yang lebih baik untuk mengontrol perilaku manajemen dalam melaporkan kinerja perusahaan agar pelaporan kinerja lebih obyektif.

\section{DAFTAR PUSTAKA}

Algifari. 1997. Statistik Induktif Untuk Ekonomi Dan Bisnis. Yogyakarta: Akademi Manajemen Perusahaan YKPN.

Arikunto, Suharsimi. 1998. Prosedur Penelitian suatu Pendekatan Praktek, Edisi Revisi IV. Jakarta: PT Rineka Cipta.

Mories, Alfan. 2002. Informasi Tentang Krisis Keuangan yang Melanda Asia Pertengahan Tahun 1997. Kompas 18 April 2002.

Darmawati, Deni. 2003. Good Corporate Governance dan Manajemen Laba: Suatu Studi Empiris. Jurnal Bisnis dan Akuntansi, Vo1.S,No.1, Hal 47-69.

Hastuti, Dwi Theresia. 2000. Hubungan Antara Good Corporate Governanve Dan Struktur Kepemilikan Dengan Kinerja Keuangan. Makalah disajikan dalam Simposium Nasional Akuntansi VIII, Ikatan Akuntan Indonesia Kompartemen Akuntan Pendidik. Uniga Soegijapranata Solo.

Helfret, E.A. 1996. Teknik Analisis Keuangan. Edisi Kedelapan. Jakarta: Penerbit Erlangga Jakarta.

Hoesada. 2000. State Of Art Pengembangan Corporate Governance Di Indonesia. Media Akuntansi. No.7/TH.1/Maret: VIII-XII.

Husnan, Suad. 2000. Corporate Governance Di Indonesia: Pengamatan Terhadap Sektor Corporate Dan Keuangan, Program Magister Hukum. Yogyakarta: UGM.

IAI. 1996. Standar Akuntansi Keuangan: Salemba Empat.

IAI. 1999. Standar Akuntansi Keuangan: Salemba Empat.

Indriani dan Nurkholis. 2002. Manfaat dan Fungsi Komite Audit dalam Mewujudkan Tata Pengelolaan Perusahaan yang Baik (Good Corporate Governance): Persepsi Manajemen Perusahaan Go Publik, TEMA (Telaah Ekonomi, Manajemen dan Akuntansi), Vol. III, No.1, Hal 37-57.

Indriantono, Nur dan Supomo Bambang. 1999. Metodologi Penelitian Bisnis: Untuk Akuntansi dan Manajemen, Edisi Pertama. Yogyakarta: BPFE

Jakarta stock Exchange, Informasi Tentang Konsep Good Corporate Governance, (Outline), (http:// www.jsx.co.id, diakses 20 Juni 2007).

Jensen Michael C. And William H.Meckling. 1976. Theory Of The Firm Management Behavior, Agency Cost And Ownership Structure Journal Of Finance Economic, Oktober.

Mayangsari, Sekar. 2003. Analisis Pengaruh Independensi, Kualitas Audit serta Mekanisme Corporate Governance terhadap Integritas Laporan 
Keuangan. Makalah disajikan dalam Simposium Nasional Akuntansi VI, Ikatan Akuntansi Indonesia Kompartemen Akuntan Pendidik, Universitas Airlangga Surabaya.

Midiastuty dan Machfoedz. 2003. Analisis Hubungan Mekanisme Corporate Governance Dan Indikasi Manajemen Laba. Makalah disajikan dalam Simposium Nasional Akuntansi VI, Ikatan Akuntan Indonesia Kompartemen Akuntan Pendidik, Universitas Airlangga Surabaya.

Nurhayani. 2004. Analisis Pengaruh independensi, Kualitas Audit dan Mekanisme Good Corporate Governance terhadap Integritas Laporan Keuangan (Studi Empiris pada Perusahaan Publik yang tercatat di Bursa Efek Jakarta). Skripsi. Tidak dipublikasikan, Malang, Fakultas Ekonomi Universitas Islam Malang.

Sugiono. 2001. Metodologi Penelitian Administrasi. Bandung: Alfabeta.

Suja'I, Yusuf, I. 2000. Manajemen Keuangan, Buku Kesatu. Penerbit: Fakultas Ekonomi Universitas Islam Malang. Buku Tidak Dipublikasikan.

Syamsuddin L. 2001. Manajemen Keuangan Perusahaan Konsep Aplikasi Dalam Perencanaan Pengawasan Dan Pengambilan Keputusan. Edisi Baru. Jakarta: Penerbit PT.Grafindo Persada.

Van Horne, James, C., dan Machowicz. J.M.Jr. 1997. Prinsip-Prinsip Manajemen Keuangan. Edisi Kesembilan. Jakarta: Penerbit: Salemba Empat.

Warsono. 2003. Manajemen Keuangan Perusahaan. Edisi Ketiga. Malang: Bayumedia Publishing, Malang.

Weston, JF., dan Coppeland. 1995. Manajemen Keuangan. Edisi Kesembilan. Jakarta: Penerbit Erlangga. 